\title{
Inspiratory loading exercises on respiratory muscle function in post-operative gastroplasty patients: a randomized clinical trial
}

\author{
Exercícios com carga inspiratória na função muscular respiratória \\ no pós-operatório de gastroplastia: um ensaio clínico randomizado
}

Ejercicios con carga inspiratoria en la función muscular respiratoria en el postoperatorio de gastroplastia: un ensayo clínico aleatorizado

\section{Maura Rigoldi Simões da Rocha ${ }^{\circledR a]}$, Daniela Faleiros Bertelli Merino ${ }^{[a]}$, Stefane Cristina de Souza $₫$ [a], Maria Imaculada de Lima Montebelo $₫{ }^{[a]}$, Irineu Rasera-Júnior ${ }^{[b]}$, Eli Maria Pazzianotto-Forti $\odot$ [a] ${ }^{*}$}

[a] Universidade Metodista de Piracicaba (Unimep), Piracicaba, SP, Brazil

[b] Clínica Bariátrica de Piracicaba, Piracicaba, SP, Brazil

\section{Abstract}

Introduction: The gastroplasty post-operative period can alter respiratory mechanics and predispose patients to respiratory complications. Objective: The objective was to evaluate the effects of exercises with inspiratory load on respiratory muscle function and on the prevalence of atelectasis after gastroplasty. Method: 40 participants were randomly allocated into two groups: Control Group (CG), its members underwent conventional respiratory physical therapy (CRP) and the Inspiratory Load Group (ILG), its members performed exercises with linear

\footnotetext{
MRSR: MS, e-mail: maurasimoes@hotmail.com DFBM: PhD, e-mail: daniela.merino@unimep.br SCS: BS, e-mail: stefane.souza@unimep.br MILM: PhD, e-mail: milmonte50@gmail.com IRJ: PhD, e-mail: irineu@bariatrica.com.br EMPF: PhD, e-mail: eli.forti@unimep.br
} 
inspiratory pressure load, with $40 \%$ of the maximum inspiratory pressure (MIP), associated with CRP. Therapy procedures were conducted twice during the immediate post-operative period and thrice on the first postoperative day. In addition to evaluating the MIP, the nasal inspiratory pressure (NIP) and the sustained maximum inspiratory pressure (SMIP) were evaluated before and after treatment. Analysis of variance followed by the Bonferroni correction were applied considering a 5\% significance level $(p<0.05)$. Results: There was no significant difference in NIP and SMIP values when the pre- and post-operative periods were compared for the ILG; however, these values were significantly lower for the CG, also with intergroup differences in NIP values. Atelectasis prevalence was 5\% for ILG and 15\% for CG, with no intergroup difference. Conclusion: The inspiratory muscle strength and resistance of the respiratory muscles were maintained in the group that performed exercises with inspiratory load associated with CRP, with a low rate of atelectasis after gastroplasty.

Keywords: Breathing Exercises. Physical Therapy Specialty. Bariatric Surgery. Obesity. Muscle Strength.

\section{Resumo}

Introdução: $O$ pós-operatório de gastroplastia pode alterar a mecânica respiratória e predispor a complicações respiratórias. Objetivo: Avaliar os efeitos de exercícios com carga inspiratória na função muscular respiratória e na prevalência de atelectasias após gastroplastia. Método: 40 voluntárias foram alocadas randomicamente em: Grupo Controle (GC), que recebeu Fisioterapia Respiratória Convencional (FRC) e Grupo Carga Inspiratória (GCI), que executou exercícios com carga inspiratória linear pressórica com 40\% da pressão inspiratória máxima (PImáx), associados à FRC. Os tratamentos foram realizados duas vezes no pós-operatório imediato e três vezes no primeiro dia pós-operatório. Além da PImáx, foram avaliadas a pressão inspiratória nasal (PIN) e a pressão inspiratória máxima sustentada (PImáxS) antes e após o tratamento. Foi realizada análise de variância seguida de ajuste de Bonferroni, e o nível de significância estatística foi de $5 \%(p<0,05)$. Resultados: Não houve diferença significativa nos valores de PIN e na PImáxS no GCI quando comparados o pré e pós-operatório, diferentemente do GC, no qual esses valores foram significativamente menores além de diferença entre os grupos no valor de PIN. A prevalência de atelectasias foi de 5\% para GCI e 15\% para GC, sem diferenças intergrupos. Conclusão: Houve manutenção da força muscular inspiratória e da resistência dos músculos respiratórios no grupo que realizou exercícios com carga inspiratória, associado a FRC com baixo índice de atelectasias após gastroplastia.

Palavras-chave: Exercícios Respiratórios. Fisioterapia. Cirurgia Bariátrica. Obesidade. Força Muscular.

\section{Resumen}

Introducción: El postoperatorio de gastroplastia puede alterar la mecánica respiratoria y predisponer a complicaciones respiratorias. Objetivo: Evaluar los efectos de ejercicios con carga inspiratoria en la función muscular respiratoria y en la prevalencia de atelectasias después de la gastroplastia. Método: 40 voluntarias fueron asignadas en: Grupo Control (GC), que recibió Fisioterapia Respiratoria Convencional (FRC) y Grupo Carga Inspiratoria (GCI), que ejecutó ejercicios con carga inspiratoria, realizados con carga lineal inspiratoria con un 40\% de la presión inspiratoria máxima (PIM) asociados a la FRC. Ambos tratamientos se realizaron dos veces en el postoperatorio inmediato y tres veces en el primer día postoperatorio. Además de la PIM, se evaluaron la presión inspiratoria nasal (PIN) y la presión inspiratoria máxima sostenida (PImáxS) antes y después del tratamiento. Se realizó el análisis de varianza seguida de ajuste de Bonferroni. Se adoptó nivel de significancia estadística del $5 \%(p<0,05)$. Resultados: No hubo diferencia significativa en los valores de PIN y en la PImáxS en el GCI cuando se compararon en el pre y en postoperatorio, a diferencia del $G C$, en el cual estos valores fueron significativamente menores más allá de diferencia entre los grupos en el valor de PIN. La prevalencia de atelectasias fue de 5\% para GCI y 15\% para GC, sin diferencia entre grupos. Conclusión: Hubo mantenimiento de la fuerza muscular inspiratoria y de la resistencia de los músculos respiratorios en el grupo que realizó ejercicios con carga inspiratoria, asociados a la FRC, con bajo índice de atelectasias tras gastroplastia.

Palabras clave: Ejercicios Respiratorios. Fisioterapia. Cirugía Bariátrica. Obesidad. Fuerza Muscular. 


\section{Introduction}

Bariatric surgery is currently considered the gold-standard in the treatment of individuals with a body mass index (BMI) above $40 \mathrm{~kg} / \mathrm{m}^{2}$, due to its greater effectiveness in the sustained weighted loss and reduction in the risk of death [1]. However, this surgical intervention can cause additional alterations in pulmonary function and in respiratory muscle contractibility. Inherent factors to the procedure such as the anesthetic, incisions and diaphragmatic dysfunction caused by the reflexive inhibition of the diaphragm, lead to diaphragmatic paresis [2,3] and to restrictive pulmonary behavior [4].

The access route, mainly by laparotomy, can compromise the breathing pattern due to pain, inhibiting deep breathing and coughing, in addition to leading to a predominantly thoracic ventilatory muscle pattern because of the reduced diaphragmatic contribution to tidal volume generation [5]. The mechanical reflex to attenuate pain in the incisional region, associated with irritation of the visceral afferent pathways, also contributes to the promotion of diaphragmatic dysfunction, resulting in reduced diaphragmatic and global mobility [6].

Diaphragmatic dysfunction can vary from partial losses in the capacity to generate pressure to the complete loss in diaphragmatic function [7], and, according to Franco et al. [8], there is evidence that this is the main cause in the etiology of pulmonary complications. This could be due to the peak in dysfunction which occurs between two and eight hours after surgery, and its function is only reestablished after about fifteen days, according to Romanini et al. [9].

Thus, the association of these factors contributes to the occurrence of pulmonary complications, which occurs in 5 to $30 \%$ of the cases during the post-operative period after abdominal surgery, being the main causes of morbidity and mortality, of increases in hospitalization time and hospital costs [10]. Atelectasis, the most frequent pulmonary complication, appears a few minutes after inducing the anesthetic, and its adverse effects persist during the post-operative period and may affect patient recovery [11-13].

Post-operative respiratory physical therapy promotes benefits in obese people such as the restoration of pulmonary volumes and capacities and in diaphragmatic mobility [14], thus contributing to the prevention of pulmonary complications [13]. Several resources are used for this procedure such as inspiratory resistive load equipment, involving resistors, orifices, springs and resistive electronic devices [15-17], which can help in preventing pulmonary complications by increasing respiratory muscle strength and resistance $[18,19]$, contributing to the early recovery of the flows and volumes in morbidly obesity patients submitted to bariatric surgery [20] and in the reduction of atelectasis and pneumonia and hospitalization time [21].

The hypothesis of this study was that using equipment with linear inspiratory pressure load could contribute to a more effective reversal of the diaphragmatic dysfunction found in the postoperative period after bariatric surgery, and thus reduce the risk of post-operative pulmonary complications. Therefore, the objective of this study was to evaluate the effects of exercises with inspiratory load on inspiratory muscle strength, on respiratory muscle resistance and on the prevalence of atelectasis in morbidly obese patients during the post-operative period after bariatric surgery.

\section{Methodology}

Study design

This was a randomized, blind clinical trial with morbidly obese participants, candidates for elective bariatric surgery, conducted for 24 months including the recruitment and medical monitoring periods, starting in March 2013 and finishing in March 2015.

\section{Ethical aspects}

The study was performed in accordance to resolution no. 466/12 of the Brazilian National Health Council, ensuring the basic bioethical references. The study was approved by the Research Ethics Committee Universidade Metodista de Piracicaba (UNIMEP), Brazil, report no. 89/12 and included in the Clinical Trials under no. NCT02682771. All participants signed informed consent forms.

\section{Sample}

\section{Inclusion criteria}

Only female participants were included, since these constituted most of the population submitted 
to this procedure thus minimizing possible biases. Participants were aged between 25 and 55, non-smokers, with BMI ranging from $\geq 40 \mathrm{~kg} / \mathrm{m}^{2}$ to $<55 \mathrm{~kg} / \mathrm{m}^{2}$ and, submitted to laparoscopic Roux-en-Y gastric bypass procedure. As additional inclusion criteria were performing pre-operative pulmonary function tests and thorax X-rays with results within the parameters of normality, no history of chronic pulmonary disease, no diagnosis of obstructive sleep apnea syndrome or the need for prior use of positive airway pressure.

\section{Exclusion criteria}

The exclusion criteria considered participants who showed hemodynamic instability, the presence of surgical complications (fistula at the clipping line, gastrointestinal bleeding, intestinal obstruction) or other less frequent complications which prolonged the expected hospitalization period (three days), those who were not in accordance to the surgical team protocol, who refused to take part in the study until its completion or who were unable to understand the evaluation procedures.

\section{Evaluations}

Anthropometric data

Body mass was obtained using a Welmy model W200/5 digital scale (Santa Bárbara d'Oeste, São Paulo, Brazil) with a maximum capacity of $200 \mathrm{~kg}$. Participants were requested to remove all clothing accessories and shoes and to use lightweight clothes. During data collection patients remained in an upright position at the center of the scale without moving and with their arms stretched at the side of the body, uniformly distributing the body weight between the feet [22]. Height was measured using a stadiometer built-in the scale. BMI was calculated according to the equation: body mass $(\mathrm{kg}) /$ height $\left(\mathrm{m}^{2}\right)^{2}$.

\section{Inspiratory muscle strength}

\section{Maximum inspiratory pressure}

The maximum inspiratory pressure (MIP) was measured to prescribe the inspiratory load on POWERbreathe $\mathrm{K} 3^{\circledR}$. Inspiratory muscle strength was evaluated by MIP using a digital MVD $300^{\circledR}$ manovacuometer (GlobalMed, RS, Brazil) from the residual volume (RV) [23], considering attempts sustained for at least one second. For this measurement the participants were requested to remain in sitting position with their feet supported and using a nasal clip. Three to five attempts at maximum inspiration were made, technically acceptable and reproducible (i.e., without air leakage and with a $10 \%$ or less difference between the values), and the highest value was used in the analysis [24].

\section{Nasal inspiratory pressure}

Nasal inspiratory pressure (NIP) was evaluated using the Sniff technique, generating a nasal pressure peak during the procedure [25]. A digital MVD $300^{\circledR}$ manovacuometer (GlobalMed, RS, Brazil) was used, with the participant in sitting position with their feet supported. One nostril was kept free while the other was occluded with a silicone nasal plug and connected to the digital manovacuometer using an approximately $1 \mathrm{~mm}$ diameter catheter [26]. Participants were asked to make a maximum sniff with the mouth closed from the functional residual capacity (FRC). The procedure was repeated ten times [27] with 30-second intervals between each sniff. The criterion used for an acceptable sniff was the generation of the greatest pressure peak and duration of between 0 and 5 seconds [28].

\section{Respiratory muscle resistance}

\section{Sustained maximum inspiratory pressure}

The incremental test for the resistance of the inspiratory muscles using the POWERbreathe $\mathrm{K} 3{ }^{\circledR}$ equipment (Gaiam Ltd; Southam, Warwickshire, UK) was performed in a pioneering way in this study. Participants were in sitting position using a nasal clip, they were instructed to breathe in strongly and deeply followed by completely breathing out, being encouraged to reach maximum performance during the test. The device emitted an acoustic signal as the sign of a new respiratory cycle after expiration ended and air flow stopped [29]. The test started with $30 \%$ of the MIP [30,31], and a $10 \mathrm{cmH}_{2} 0$ load [32] added after every 30 respiratory cycles. At the end of each step, the participant rested for 1 minute before starting again. The test continued until the patient could no longer manage to generate the predetermined pressure by three consecutive respirations or presented dyspnea. Thus, when the participant met these criteria the test was stopped and the greatest load sustained for at least 
15 respirations was considered as the value of the sustained maximum inspiratory pressure (SMIP).

A differential of the device used is that the load is digitally adjusted and provides the power data (muscle performance), tidal volume and training index (TI) (inspiratory muscle activity intensity) data, which aid in the evaluation of the behavior of the respiratory muscles [29].

\section{Pulmonary complications}

For all the participants under treatment, the presence of post-operative pulmonary complications, as described in the medical file, was analyzed during the hospitalization period. They were defined as: acute respiratory failure characterized by the need for tracheal intubation and mechanical ventilation -, pleural effusion, pneumothorax, atelectasis and pneumonia. The presence of complications was based on image exams, on clinical and laboratory exams and on the institution of antibiotic therapy [19].

\section{Thoracic X-rays}

Thoracic X-rays were conducted on the day of hospital discharge. Participants were in the upright position, incident on the posterior-anterior region, according to the hospital protocol.

Thoracic X-ray reports were emitted by the hospital radiologists, who were blinded in relation to which groups the participants had been assigned. All participants whose reports mentioned the terms "atelectasis", "pulmonary hypoexpansion" or pulmonary field(s) hypoexpansion, regardless of the location and dimension, were considered as presence of atelectasis.

Post-operative evaluation was conducted on the day the participants were discharged from the hospital, i.e., on the second post-operative day, according to the protocol of the surgical team. The tests to verify NIP and SMIP values were conducted again. The presence of pain was verified using a visual analogue scale (VAS) to minimize its interference. The scale ranged from zero to ten and associated facial expressions according to each evaluated sensation, where 0 was considered the total absence of pain and 10 the maximum pain level supported. Thus, before starting the test, participants classified the level of pain felt at that moment [33]. If the pain intensity reported was greater than or equal to 4 , the nursing team was requested to apply a pain reliever according to the medical prescription. After 30 minutes, the participant was requested to classify her pain again, and the evaluation only began when the intensity was less than or equal to 3 .

\section{Assignment of the participants to each group}

Participants evaluated in the pre-operative phase were randomized by the Excel software and assigned to two groups: Control group (CG) with 21 participants and the Inspiratory load group (ILG) with 22 participants.

CG participants were submitted to conventional respiratory physical therapy (CRP) sessions, which consisted of diaphragm respiratory exercises, deep and fractioned inspirations, respiratory exercises associated with upper limb movements and the use of incentive spirometry. Each exercise was performed with a series of 10 repetitions, in addition to ambulation [34].

A Respiron ${ }^{\circledR}$ model Classic dependent flow device (NCS, São Paulo, Brazil) was used to conduct the incentive spirometry exercise, aimed at increasing pulmonary expansion. The unit used in this study had three plastic chambers, each containing a small colored sphere that moved freely upwards or downwards in the chamber. When the patient inspired deeply, the spheres moved upward successively due to negative pressure generated at the upper extremities of the chambers, visually encouraging the patient to breathe deeply. The instructions for use were based on the recommendations of the American Association for Respiratory Care (AARC) [35]. Participants were asked to perform maximum and slow inspirations with sufficient flow to raise and sustain the three spheres as long as possible.

For these procedures, the participants were preferentially in seating position or, when not possible, lying down comfortably on their backs in a 45을 Fowler semi-upright position, having their arms and shoulders relaxed.

In addition to CRP, the ILG underwent linear inspiratory pressure load exercises using the POWERbreathe K3 device. This is a digital device is used to train the inspiratory muscles, featuring a rapid, electronically controlled response valve, enabling the inspiratory resistance to be adjusted. The device also features a data storage system that 
shows previous data. The resistance used was $40 \%$ of the MIP measured in the pre-operative period. The participant was instructed to breathe in to overcome the resistance of the equipment and then breathe out normally. Six series of fifteen repetitions were conducted, with 30 to 60 -second interval between each series.

The sessions for both groups were applied with the same frequency, i.e., twice immediately after the procedure and thrice on the first post-operative day (every 6 hours).

It must be noted that no adverse effects occurred during the intervention period.

\section{Blinding}

Researchers responsible for the randomization and data treatment and the radiologist responsible for the thoracic X-ray reports were blinded in relation to the evaluation of the treatments. The person responsible for the interventions was blinded to the evaluation and the evaluator blinded to the interventions. Participants were blinded to the treatments.

\section{Statistical analysis}

Sample size was calculated by descriptive statistics using version the BioEstat version 5.3 software based on the first six participants of the intervention group, considering the nasal inspiratory pressure (NIP) and sustained maximum inspiratory pressure (SMIP) variables. The mean of the differences (considering before and after intervention) and the standard deviations of the differences were used in the calculation using t-test for paired samples, adopting a 0.05 alpha and $90 \%$ statistical power. The variable with the largest sample was considered for the study, which was NIP (differences mean $=6.67$; standard deviation \pm 9.46 and a unilateral test). Thus 19 participants were designated for each group, resulting in a sample constituted of a minimum of 38 participants in total. Considering a $20 \%$ sample loss, 47 participants were screened and evaluated.

The data were analyzed using the SPSS version 17.0 software, and the normality of data distribution was assessed by the Shapiro-Wilk test. Anthropometric characteristics and ages were compared using Student's t-test for parametric data and Mann-Whitney's test for non-parametric data. The analysis of variance with repeated measurements (ANOVA) was used for intraand intergroup comparisons of the inspiratory muscle strength and respiratory muscle resistance variables, followed by the Bonferroni correction. Sphericity assumption was tested using Mauchly's test, and when no assumption was found, the Greenhouse-Geisser (GG) correction was applied. Data were presented in confidence intervals considering a $95 \%$ level. The Chi-squared test was used to compare the prevalence of atelectasis in each group. All the tests were processed considering a 5\% significance level.

Moreover, the possible influence of the treatment of the outcome variables was tested using the Effect Size measurement to analyze the treated groups in relation to the control group. Cohen's $d$ method was used for this in the Effect Size Generator version 2.3 software (Swinburne University of Technology, Center for Neuropsychology, Melbourne, Australia), considering the mean and standard deviation of the differences between the pre- and post-operative periods and the number of participants in each group. Cut-off points were used to interpret the results to classify the size of the effect. Values equal to or greater than 0.8 represented a large effect, between 0.2 and 0.8 a moderate effect and below 0.2 a small effect [36].

\section{Results}

Of the 47 participants evaluated, 4 were excluded from the study, and of the 43 randomized, 3 were not reevaluated, for 40 participants in total who were included in the study (Figure 1).

Table 1 shows the results obtained for the participants' ages and anthropometric characteristics. Results show that there was no difference between the groups for the age and anthropometric characteristics variables ( $p>0.05)$.

Table 2 shows the values found for the variables of strength (NIP measurements) and the variables for the respiratory muscle resistance test (SMIP, Power, Volume and Training Index) in the pre- and post-operative periods. The values for NIP, SMIP, Power and TI remained the same for ILG, but all variables changed for the CG. When comparing the groups, there were differences for the NIP, power and TI variables due to the decrease in values for the CG. 


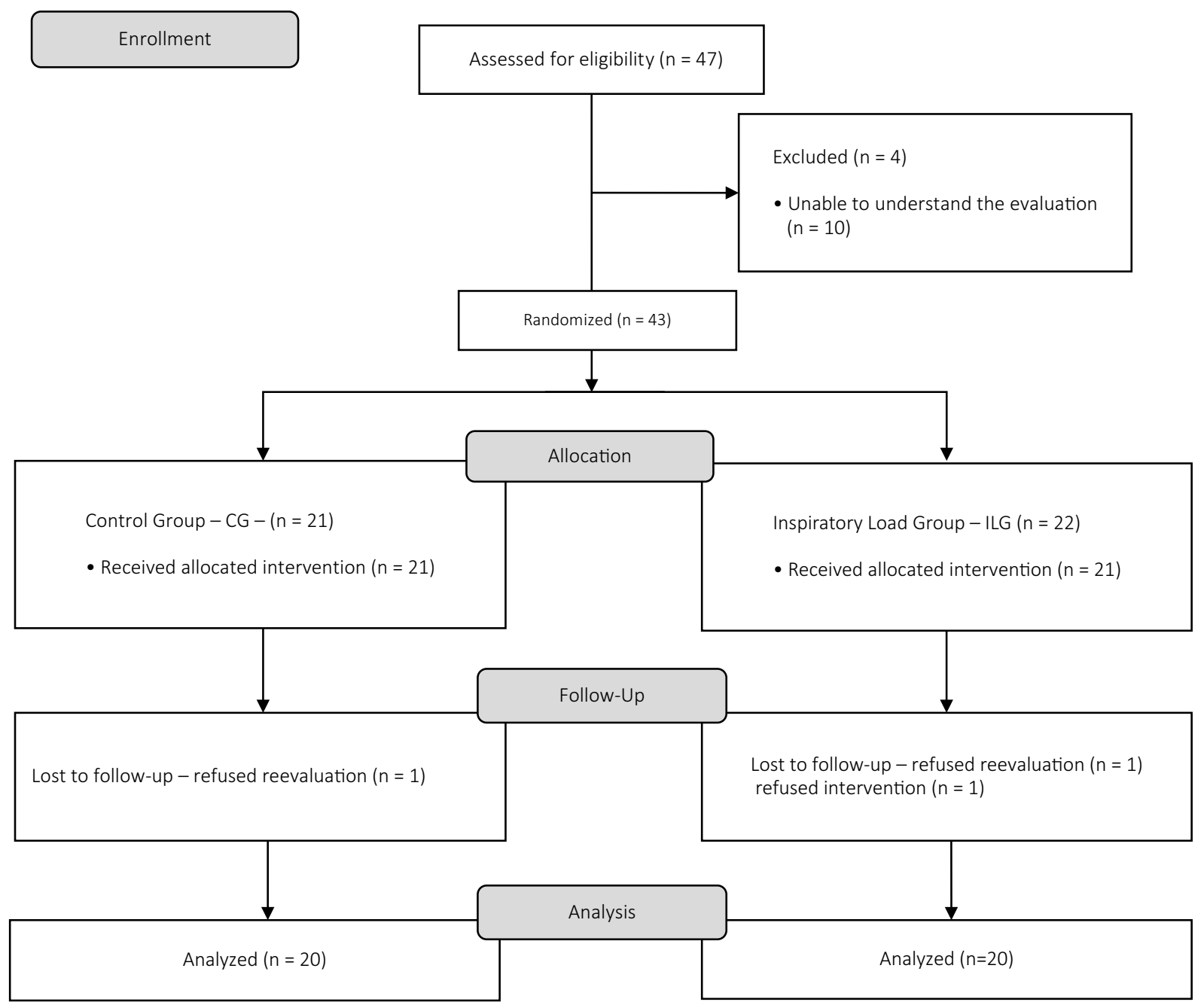

Note: $\mathrm{n}$ : number of participants in the group; CG: control group; ILG: inspiratory load group.

Figure 1 - Flowchart of the study design according to CONSORT.

Table 1 - Age, anthropometric characteristics and surgeries of the participants assigned to the groups

\begin{tabular}{lccc}
\hline & $\begin{array}{c}\text { CG } \\
(\mathbf{n}=\mathbf{2 1})\end{array}$ & $\begin{array}{c}\text { ILG } \\
(\mathbf{n}=\mathbf{2 2})\end{array}$ & p value \\
\hline Age (years) & $40.45 \pm 9.59$ & $36.9 \pm 5.92$ & 0.14 \\
Body mass (kg) & $114.4 \pm 14.46$ & $116.83 \pm 12.95$ & 0.60 \\
Height (cm) & $161.1 \pm 7.81$ & $161.9 \pm 6.24$ & 0.69 \\
BMI (kg/m $\mathbf{m}^{2}$ & $44.02 \pm 3.42$ & $44.66 \pm 4.06$ & 0.60 \\
Anesthetic-extubation induction (min) & $130.17 \pm 12.75$ & $129.15 \pm 15.35$ & 0.58 \\
MV time (min) & $127.15 \pm 11.75$ & $126 \pm 11.22$ & 0.64 \\
\hline
\end{tabular}

Note: BMl: body mass index; $\mathrm{n}$ : number of participants; $\mathrm{cm}$ : centimeter; $\mathrm{Kg}$ : kilogram; $\mathrm{m}^{2}$ square meter; min: minute; MV: mechanical ventilation; CG: control group; ILG: inspiratory load group. Values expressed as mean \pm standard deviation - Student's t-test and Mann-Whitney's test. 
Table 2 - Values obtained for NIP, SMIP, power, volume and the training index in the pre- and post-operative periods

\begin{tabular}{|c|c|c|c|c|c|c|c|c|}
\hline Variable & & & Mean & Standard error & & & $\begin{array}{c}\text { p value } \\
\text { intragroup }\end{array}$ & $\begin{array}{c}\text { p value } \\
\text { intergroup }\end{array}$ \\
\hline \multirow{4}{*}{$\begin{array}{c}\mathrm{NIP} \\
\left(\mathrm{cmH}_{2} \mathrm{O}\right)\end{array}$} & \multirow{2}{*}{$C G$} & Pre- & 76.7 & 2.9 & 70.8 & 82.5 & \multirow{2}{*}{$<0.001$} & \multirow{4}{*}{0.02} \\
\hline & & Post- & 57.7 & 3.8 & 50 & 65.4 & & \\
\hline & \multirow{2}{*}{ ILG } & Pre- & 87.2 & 2.9 & 81.3 & 93 & \multirow{2}{*}{0.13} & \\
\hline & & Post- & 80.6 & 3.8 & 72.8 & 88.3 & & \\
\hline \multirow{4}{*}{$\begin{array}{c}\text { SMIP } \\
\left(\mathrm{cmH}_{2} 0\right)\end{array}$} & \multirow{2}{*}{ CG } & Pre- & 39 & 1.9 & 35 & 40 & \multirow{2}{*}{0.004} & \multirow{4}{*}{0.44} \\
\hline & & Post- & 33 & 1.3 & 30.3 & 35.7 & & \\
\hline & \multirow{2}{*}{ ILG } & Pre- & 42 & 2.4 & 37.1 & 46.9 & \multirow{2}{*}{0.2} & \\
\hline & & Post- & 38.5 & 1.8 & 34.7 & 42.3 & & \\
\hline \multirow{4}{*}{$\begin{array}{l}\text { Power } \\
\text { (W) }\end{array}$} & \multirow{2}{*}{$C G$} & Pre- & 2.9 & 0.3 & 2.3 & 3.5 & \multirow{2}{*}{0.009} & \multirow{4}{*}{0.002} \\
\hline & & Post- & 1.9 & 0.3 & 1.4 & 2.4 & & \\
\hline & \multirow{2}{*}{ ILG } & Pre- & 3.1 & 0.3 & 2.5 & 3.7 & \multirow{2}{*}{0.2} & \\
\hline & & Post- & 2.7 & 0.3 & 2.1 & 3.2 & & \\
\hline \multirow{4}{*}{$\begin{array}{l}\text { Volume } \\
\text { (L) }\end{array}$} & \multirow{2}{*}{ CG } & Pre- & 1.3 & 0.1 & 1.1 & 1.4 & \multirow{2}{*}{0.005} & \multirow{4}{*}{0.1} \\
\hline & & Post- & 1 & 0.1 & 0.9 & 1.1 & & \\
\hline & \multirow{2}{*}{ ILG } & Pre- & 1.4 & 0.1 & 1.2 & 1.5 & \multirow{2}{*}{0.009} & \\
\hline & & Post- & 1 & 0.1 & 0.9 & 1.1 & & \\
\hline \multirow{4}{*}{$\begin{array}{c}\mathrm{TI} \\
(\%)\end{array}$} & \multirow{2}{*}{$C G$} & Pre- & 67.9 & 5.5 & 56.7 & 79 & \multirow{2}{*}{0.03} & \multirow{4}{*}{0.01} \\
\hline & & Post- & 40.7 & 8.7 & 23.1 & 58.2 & & \\
\hline & \multirow{2}{*}{ ILG } & Pre- & 80.7 & 5.5 & 69.5 & 91.8 & \multirow{2}{*}{0.73} & \\
\hline & & Post- & 78.1 & 8.7 & 60.6 & 95.6 & & \\
\hline
\end{tabular}

Note: CG: control group; ILG: inspiratory load group; n: number of participants; Pre-: pre-operative period; Post-: post-operative period; NIP: nasal inspiratory pressure; $\mathrm{CmH}_{2} \mathrm{O}$ : centimeters of water; SMIP: sustained maximum inspiratory pressure; $\mathrm{W}$ : watt; $\mathrm{L}$ : liter; TI: training index; significant difference $(p<0.05)$. Values expressed as mean, standard error and confidence interval of the mean - ANOVA test followed by the Bonferroni correction.

Table 3 shows the size of the effect of the treatment, a great effect on NIP and a moderate effect on SMIP being observed for ILG in relation to CG.

Table 3 - Size of the effect of the treatment for the treated groups as compared to the control group for the variables of NIP and SMIP

\begin{tabular}{lcc}
\hline \multicolumn{3}{c}{ Cohen's $\boldsymbol{d}$} \\
\hline & & ILG \\
\hline Inspiratory muscle strength & NIP & $1.49^{\star *}$ \\
& IC (95\%) & 0.79 to 2.19 \\
\cline { 2 - 3 } Respiratory muscle resistance & SD & 9.64 \\
\cline { 2 - 3 } & SMIP & $0.25^{\star}$ \\
& IC (95\%) & -0.38 to 0.87 \\
& SD & 10.18 \\
\hline
\end{tabular}

Note:ILG: inspiratory load group; IC: interval of confidence; SD: standard deviation; *: Moderate effect (between 0.2 and 0.8 ); **: Great effect $(>0.8)$. Effect size evaluated by the Cohen's $d$ method.
The prevalence of atelectasis was $15 \%$ for the CG and $5 \%$ for the ILG, but with no significant difference between the groups $(p=0.51)$.

\section{Discussion}

This study showed the maintenance of the strength, respiratory muscle resistance, power and training index by the group that performed the exercises with an inspiratory load associated with CRP. These findings were relevant since the pulmonary mechanics were directly changed due to intubation, the general anesthetic procedure, immobility, the use of neuromuscular blocks and invasive mechanical ventilation. Moreover, the surgical incision and the presence of pain are factors present in upper abdominal surgery [2, 37-39], having diaphragmatic dysfunction being considered the main cause of pulmonary compromise $[40,41]$, and these factors 
could explain the findings in the control group, in which the values of all studied variables dropped.

Thus, CRP associated with the respiratory exercises promoted additional gains in relation to respiratory muscle function in the post-operative period after gastroplasty.

The reduction in MIP during the post-operative reflects the diaphragmatic dysfunction [8] observed in this study, which is caused by the decrease in NIP. We must note that NIP is considered an alternative technique to evaluate the overall strength of the diaphragm and other inspiratory muscles in a noninvasive way [42, 43]. This procedure was validated according to the MIP, presenting accuracy and good correlation, involving reduced risk of fatigue due to staying for less time at the pressure peak, as well as an easier and more physiological execution [43]. In addition to promoting greater comfort, these advantages should be considered when performing it on post-operative patients [44], as in this study. According to Siafakas et al. [2], the decrease in NIP identifies the muscle inefficiency promoted by inherent factors of the surgical procedure, as previously described. On the other hand, the maximum expiratory pressure (MEP), although not evaluated in this study, decreased according to Laghi \& Tobim [41] due to the surgical incision.

Casali et al. [20] conducted exercises with resistive inspiratory load in the post-operative period after laparoscopic bariatric surgery. Despite the significant reduction in the spirometric parameters such as the forced vital capacity and respiratory muscle strength on the second post-operative day, the respiratory muscle strength of the group that received the intervention returned to basal values before the control group. Both groups were followed-up to the $30^{\text {th }}$ post-operative day, when the control group still showed 8\% MIP loss, whereas the group that used the inspiratory muscle load showed a $13 \%$ gain.

Some studies, such as those of Kulkarni et al. [18] and Edwards et al. [45] have shown that inspiratory muscle training (IMT) in the pre-operative period increases the MIP, which can improve the respiratory conditions of patients who will undergo surgery. In the first study conducted with IMT using a linear pressure load device for two pre-operative weeks to abdominal surgery, a significant increase in inspiratory muscle strength was observed and this value was maintained during the post-operative period, when compared to the control group and the group that used incentive spirometry during the post-operative period. On the other hand, in the second study, after 4 weeks of IMT in overweight and obese individuals, in addition to an increase in MIP, a greater distance was covered in the 6-minute walk test.

The exercise program with inspiratory load used in this study as a proposal for intervention should not be understood as an IMT program, since the time used was too short to produce a change in the type of muscle fibers. However, preservation of the respiratory muscle strength - as evidenced by MIP maintenance - could contribute to a decrease in dyspnea, tolerance to exercise and the prevention of pulmonary complications since, according to Souza et al. [46] the decrease in respiratory muscle strength and resistance could be related to exercise intolerance and higher dyspnea indices.

We must highlight that the incremental resistance test using the POWERbreathe device was performed in a pioneering way in this study. Respiratory muscles resistance is defined as the capacity to sustain a minute level of ventilation (ventilation resistance) or a given level of inspiratory, and sometimes expiratory, pressure. Thus, both the sustained maximum inspiratory pressure (SMIP) during the incremental load test and the time to exhaustion on breathing in against a constant sub-maximum load (tlim) are commonly used for this purpose [33]. Therefore, the incremental test was applied and its outcome was the sustained maximum inspiratory pressure (SMIP). Regarding the variables that could be obtained from the SMIP, the ILG also managed to ensure a lower decrease in the TI, suggesting the maintenance of muscle performance, but not maintaining the amount of air inspired during the incremental test.

The results about the effect size of the treatment, evaluated considering the Effect Size, corroborated the benefits of the proposed intervention, demonstrating a great effect on the NIP and moderate effect on the SMIP of the ILG when compared to the CG.

Regarding the low prevalence of atelectasis (5\%) for the ILG, this may have occurred due to maintenance of the expiratory reserve volume, which is associated with the residual functional capacity, favoring greater pulmonary stability. Even the CG, which presented a $15 \%$ prevalence, showed the importance of respiratory physical therapy, since, according to Baltieri et al. [47], the incidence of atelectasis in the post-operative period after bariatric surgery can reach $37.8 \%$. It must be mentioned that all atelectasis cases were 
sub-clinical, causing no functional impact and no other pulmonary compromise was found, thus justifying the early start of physical therapy sessions and the number of sessions used, suggesting the effectiveness of the interventions in both groups.

\section{Study limitations}

Due to the pioneering use of POWERbreathe in the incremental respiratory muscle resistance test, studies on its validity and reproducibility are fundamental. Thus, the authors' research group is preparing such studies.

\section{Conclusion}

Considering the results presented, we can conclude that despite the short treatment time, exercises with inspiratory load, associated with conventional respiratory physical therapy were capable of maintaining the inspiratory muscle strength and respiratory muscle resistance of the participants, which could contribute to an earlier reversal of diaphragmatic dysfunction and preventing pulmonary complications, as evidenced by low atelectasis levels.

\section{References}

1. Trindade EN, Zanella EP, Blume CA, von Diemen V, Cardoso S, Belline V, et al. Cirurgia para tratamento da obesidade mórbida: princípios básicos. Rev HCPA. 2013;33(2):142-9.

2. Siafakas N, Mistrouska I, Bouros D, Georgopoulos D. Surgery and the respiratory muscles. Thorax. 1999;54(5):458-65.

3. Tenório LHS, Lima AMJ, Brasileiro-Santos MS. Intervenção da fisioterapia respiratória na função pulmonar de indivíduos obesos submetidos à cirurgia bariátrica: uma revisão. Rev Port Pneumol. 2010;16(2):307-14.

4. Costa D, Forti EMP, Barbalho-Moulim MC, Rasera-Junior I. Estudo dos volumes pulmonares e da mobilidade toracoabdominal de portadoras de obesidade mórbida, submetidas à cirurgia bariátrica, tratadas com duas diferentes técnicas de fisioterapia. Rev Bras Fisioter. 2009;13(4):294-300.
5. Tonella RM, Araújo S, Silva AMO. Estimulação elétrica nervosa transcutânea no alívio da dor pós-operatória relacionada com procedimentos fisioterapêuticos em pacientes submetidos a intervenções cirúrgicas abdominais. Rev Bras Anestesiol. 2006;56(6):630-42.

6. Silva EF, Guedes RP, Ribeiro EC. Estudo das repercussões das cirurgias abdominais sobre os músculos respiratórios. Fisioter Mov. 2003;16(1):51-6.

7. McCool FD, Tzelepis GE. Dysfunction of the diaphragm. N Engl J Med. 2012;366(10):932-42.

8. Franco AM, Torres FCC, Simon ISL, Morales D, Rodrigues AJ. Assessment of noninvasive ventilation with two levels of positive airway pressure in patients after cardiac surgery. Rev Bras Cir Cardiovasc. 2011;26(4):582-90.

9. Romanini W, Muller AP, Carvalho KAT, Olandoski M, Faria-Neto JR, Mendes FL, et al. Os efeitos da pressão positiva intermitente e do incentivador respiratório no pós-operatório de revascularização miocárdica. Arq Bras Cardiol. 2007;89(2):105-10.

10. Dronkers J, Veldman A, Hoberg E, van der Waal C, van Meeteren N. Prevention of pulmonary complications after upper abdominal surgery by preoperative intensive inspiratory muscle training: a randomized controlled pilot study. Clin Rehabil. 2008;22(2):134-42.

11. Eichenberger A, Proietti S, Wicky S, Frascarolo P, Suter M, Spahn DR, et al. Morbid obesity and postoperative pulmonary atelectasis: an underestimated problem. Anesth Analg. 2002;95(6):1788-92.

12. Duggan M, Kavanagh BP. Pulmonary atelectasis: a pathogenic perioperative entity. Anesthesiology. 2005;102(4):838-54.

13. Pelosi P, Gregoretti C. Perioperative management of obese patients. Best Pract Res Clin Anaesthesiol. 2010;24(2):211-25.

14. Brigatto P, Carbinatto JC, Costa CM, Montebelo MIL, Rasera-Júnior I, Pazzianotto-Forti EM. Aplicação de pressão positiva nas vias aéreas na restauração da função pulmonar e da mobilidade torácica no pósoperatório de cirurgia bariátrica: um ensaio clínico randomizado. Braz J Phys Ther. 2014;18(6):553-62. 
15. Llórens J, Rovira L, Ballester M, Moreno J, HernándezLaforet J, Santonja FJ, et al. Preoperative inspiratory muscular training to prevent postoperative hypoxemia in morbidly obese patients undergoing laparoscopic bariatric surgery. A randomized clinical trial. Obes Surg. 2015;25(6):1003-9.

16. Madariaga VB, Iturri JB, Manterola AG, Buey JC, Sebastián NT, Peña VS. Comparison of two methods for inspiratory muscle training in patients with chronic obstructive pulmonary disease. Arch Bronconeumol. 2007;43(8):431-8.

17. McConnell AK. Respiratory muscle training: theory and practice. Edinburgh: Churchill Livingstone Elsevier; 2013. p.256.

18. Kulkarni SR, Fletcher E, McConnell AK, Poskitt KR, Whyman MR. Pre-operative inspiratory muscle training preserves postoperative inspiratory muscle strength following major abdominal surgery: a randomised pilot study. Ann R Coll Surg Engl. 2010;92(8):700-7.

19. Soares SM, Nucci LB, Silva MM, Campacci TC. Pulmonary function and physical performance outcomes with preoperative physical therapy in upper abdominal surgery: a randomized controlled trial. Clin Rehabil. 2013;27(7):616-27.

20. Casali CC, Pereira AP, Martinez JA, Souza HC, Gastaldi AC. Effects of inspiratory muscle training on muscular and pulmonary function after bariatric surgery in obese patients. Obes Surg. 2011;21(9):1389-94.

21. Katsura M, Kuriyama A, Takeshima T, Fukuhara S, Furukawa TA. Preoperative inspiratory muscle training for postoperative pulmonary complications in adults undergoing cardiac and major abdominal surgery. Cochrane Database Syst Rev. 2015;(10):CD010356.

22. Azevedo MM, Melo APR, Cabral PC. Avaliação nutricional do idoso. Rev Bras Nutr Clin. 2009;24(4):230-5.

23. Black LF, Hyatt RE. Maximal respiratory pressures: normal values and relationship to age and sex. Am Rev Respir Dis. 1969;99(5):696-702.
24. Neder JA, Andreoni S, Lerario MC, Nery LE. Reference values for lung function tests. II. Maximal respiratory pressures and voluntary ventilation. Braz J Med Biol Res. 1999;32(6):719-27.

25. Prigent $H$, Lejaille $M$, Falaize L, Louis A, Ruquet $M$, Fauroux B, et al. Assessing inspiratory muscle strength by sniff nasal inspiratory pressure. Neurocrit Care. 2004;1(4):475-8.

26. Mottram CD. Ruppel's manual of pulmonary function testing. 6th ed. St Louis: Mosby; 1994.

27. Lofaso F, Nicot F, Lejaille M, Falaize L, Louis A, Clement A, et al. Sniff nasal inspiratory pressure: what is the optimal number of sniffs? Eur Respir J. 2006;27(5):980-2.

28. Uldry C, Fitting JW. Maximal values of sniff inspiratory pressure in healthy subjects. Thorax. 1995;50(4):371-5.

29. Langer D, Jacome C, Charususin N, Scheers H, McConnell A, Decramer M, et al. Measurement validity of an electronic inspiratory loading device during a loaded breathing task in patients with COPD. Respir Med. 2013;107(4):633-5.

30. Larson JL, Covey MK, Wirtz SE, Berry JK, Alex CG, Langbein WE, et al. Cycle ergometer and inspiratory muscle training in chronic obstructive pulmonary disease. Am J Respir Crit Care Med. 1999;160(2):500-7.

31. American Thoracic Society (ATS), European Respiratory Society (ERS). ATS/ERS Statement on respiratoy muscle training. Am J Respir Crit Care Med. 2002;166:518-624.

32. Basso-Vanelli RP, Di Lorenzo VAP, Ramalho M, Labadessa IG, Regueiro EMG, Jamami M, et al. Reproducibility of inspiratory muscle endurance testing using POWERbreathe for COPD patients. Physiother Res Int. 2018;23(1):e1687.

33. Downie WW, Leatham PA, Rhind VM, Wright V, Branco JA, Anderson JA. Studies with pain rating scales. Anna Rheum Dis. 1978;37(4):378-81. 
34. Forti E, Ike D, Barbalho-Moulim M, Rasera Jr I, Costa D. Effects of chest physiotherapy on the respiratory function of postoperative gastroplasty patients. Clinics. 2009;64(7):683-9.

35. American Association for Respiratory Care (AARC). Clinical practice guideline: incentive spirometry. Respir Care. 1991;36(12):1402-5.

36. Cohen J. Statistical power analysis for the behavioral sciences. 2nd ed. Mahwah, NJ: Lawrence Erlbaum Associates; 1988.567 p.

37. Gastaldi AC, Magalhães CMB, Baraúna MA, Silva EMC, Souza HCD. Benefícios da cinesioterapia respiratória no pós-operatório de colecistectomia laparoscópica. Rev Bras Fisioter. 2008;12(2):100-6.

38. Mimica Z, Pogorelić Z, Perko Z, Srsen D, Stipić R, Dujmović D. Effect of surgical incision on pain and respiratory function after abdominal surgery: a randomized clinical trial. Hepatogastroenterolgy. 2007;54(80):2216-20.

39. Lawrence VA, Cornell JE, Smetana GW. Strategies to reduce postoperative pulmonary complications after noncardiothoracic surgery: systematic review for the American College of Physicians. Ann Intern Med. 2006;144(8):596-608.

40. Ramos GC, Pereira E, Neto SG, de Oliveira EC. Avaliação da função pulmonar após colecistectomias laparoscópicas e convencionais. Rev Col Bras Cir. 2007;34(5):326-30.

41. Laghi F, Tobin MJ. Disorders of the respiratory muscles. Am J Respir Crit Care Med. 2003;168(1):10-48.

42. Héritier F, Rahm F, Pasche P, Fitting JW. Sniff nasal inspiratory pressure: a noninvasive assessment of inspiratory muscle strength. Am J Respir Crit Care Med. 1994;150(6 Pt 1):1678-83.

43. Souza RB. Pressões respiratórias estáticas máximas. J Pneumol. 2002;28(Supl 3):S155-65.
44. Graetz JP, Zamunér AR, Moreno MA. Evaluation of maximal inspiratory and sniff nasal inspiratory pressures in pre- and postoperative myocardial revascularization. Rev Bras Cir Cardiovasc. 2012;27(4):607-13.

45. Edwards AM, Maguire GP, Graham D, Boland V, Richardson G. Four weeks of inspiratory muscle training improves self-paced walking performance in overweight and obese adults: a randomized controlled trial. J Obes. 2012;1-6.

46. Souza FP, França FJR, Oliveira MF. Fraqueza muscular respiratória compromete a capacidade de exercício em pacientes com fibromialgia. Rev Fac Cienc Med Sorocaba. 2015;17(4):199-205.

47. Baltieri L, Peixoto-Souza FS, Rasera-Jr I, Montebelo MIL, Costa D, Pazzianotto-Forti EM. Análise da prevalência de atelectasia em pacientes submetidos à cirurgia bariátrica. Rev Bras Anestesiol. 2016;66(6):577-82.

Received on $07 / 14 / 2017$

Recebido em 14/07/2017

Recibido en $14 / 07 / 2017$

Approved on 01/15/2019

Aprovado em 15/01/2019

Aprobado en 15/01/2019 